\section{Ethics Controlling. Military Medical Practice}

\section{Adina MARINESCU1, Simona GHEORGHIU²}

${ }^{1}$ Centre for Research in Applied Ethics, Faculty of Philosophy, University of Bucharest, Romania; a.marinescu@yahoo.com

${ }^{2}$ Centre for Research in Applied Ethics, Faculty of Philosophy, University of Bucharest, Romania; simona gheorghiu@yahoo.com
Abstract: Ethics controlling in medical practice is an important tool for performing a good medical act. Although ethical issues in military medicine have many similarities to civilian issues, the institutional regulations in controlling ethics are the same, the specificity of the military medical field may require the development of customized ethical control tools. In our view, ethics management is a system covering all ethical issues in medical practice. The ethical control mechanisms identified within the ethics management system (ethical regulation, the organism of controlling ethics, or medical agreement - informed consent) have the primary function to create an institutional ethical climate. The institutional mechanisms of controlling ethics are necessary to ensure a high-performance medical act and the implementation of its must be customised to the particularities generated by the context of military activity.

Keywords: ethics management; Ethical Council; military medical personnel.

How to cite: Marinescu, A., \& Gheorghiu, S. (2019). Ethics Controlling. Military Medical Practice. Logos Universality Mentality Education Novelty: Philosophy \& Humanistic Sciences, 7(1), 51-77. doi: 10.18662/lumenphs/18 


\section{Introduction}

In the decades that followed World War II and the Nuremberg trials, significant progress was made with the awareness of risks in medical practice. Once disputes over unethical behaviours occurring in medical practice, including in clinical studies, have spread to the public, preventing misconduct has become a necessity, thus requiring better ethics management at institutional level. Although ethics has always been a solution for good medical practice, it is only now that the necessary mechanisms for ethical control in medical practice are established.

The objective we have set is to verify the applicability of control mechanisms through the ethics controlling body, as part of the ethics management system of the military medical field. In our analysis of institutional ethical mechanisms, we have chosen to relate to military medical practice and compare to the civilian one. Why do we consider it useful to bring this area of activity into the foreground? Military medicine offers the opportunity to test the functioning of institutional ethics mechanisms under exceptional circumstances, with an ethical impact on the medical personnel and the community, on the one hand, and the patient on the other hand. We have chosen to review with priority the institutional body which has the role of ethics controlling of military medical activity. This mechanism provides a complex representation of ethics management, both in civilian and in military medicine. The evaluation of ethical incidence and ethical decisionmaking methods in medical practice are the responsibility of members of the ethics controlling body, like Ethics Council. For this reason, the Ethics Council functions can be expanded to the other units of medical practice as campaign hospitals in theatres of operations, through other institutional bodies, as ethical commission, ethics advisers. The institutional body of the territorial military hospitals is represented by the Ethical Council. In the medical campaign units in theatre of operation we presume the role of this body could be extended to the other type of structure. In order to have the most faithful perspective of the ethical control mechanism, we will succinctly present the main international standards of protection of human rights of the patient care, a summary of concept of ethical management, the context of the institutionalization of ethics, focusing on Ethics Council, and then we will present the ethical particularity of military medicine issues, correlated with possible practical difficulties in the implementation of the Council, identified in empirical research. 
Often the health professionals have obligations to others, besides their patients. Medical personnel have responsibilities to communities of patients, for prevention, health education and clinical care, to family members, employers, insurance companies and governments. In military medical practice, physicians obeying rules more strictly, due to particularity of hierarchical rapports in extreme situations of the military conflict. This conflictual phenomenon is named "dual loyalty". Thus, we meet our objective, from the perspective of a specialized extension of ethics, ethics management. Thus, we will be able to verify the necessity of ethical tools, more precisely the ethics controlling body in the form proposed by norms. Also, we will determine if it contributes, as part of a productive system of ethics management, to success of military medical practice.

\section{International standards on patient care and human rights}

\section{International context}

International standards on protect human rights and the patient care include mandatory treaties for all states that have ratified them, mechanisms for their monitoring compliance and instruments necessary for guiding, with non-binding feature, but so important to consider. The pioneering of ethics management occurs in the post-war period, with the condemnation of Nazi doctors for atrocities during the Second World War. The first ethical regulation measures with international application are place through the adoption of declarations, codes, conferences and thematic publications, recommendations (international directives) for the establishment of ethical issues management bodies (committees). In the medical field, including military medicine, the medical units have grounded and regulated ethics and have developed ethical and deontological codes, have formulated principles, and have adopted declarations.

International events have highlighted the importance of respecting ethical principles in medical practice. The first event that highlighted the need to adopt ethical principles was in Nürnberg (1947), where war crimes trials took place before the Military Tribunal. The Nuremberg Code, developed in 1948, contains a set of rules (ten) for doctors and researchers, which today governs medical practice. The Nürnberg Code becomes the foundation of ethical regulations in biomedical research on human subjects. As Norbert Ehrenfreund, the author of The Nuremberg Legacy, says, how war crimes have changed the course of history: "Probably the first time in the history of medical practice, patients have allotted rights for their protection." (Ehrenfreund, 2007, p. 149). The followed period of the 
"Nürnberg" moment became the most productive period in the development of medical ethics. Thus, 1947 becomes the border for a new era in bioethics through public activities (conferences) and statements with global impact.

Concerning of ethical regulation, World Medical Association have intensified the international regulation through adopting a set of declarations. "Declaration of Geneva" was adopted in 1947 by the World Medical Association. It includes a set of commitments that physicians undertake in medical practice, following the ethical principles of the medical profession. It is a modern formulation of the "Hippocratic Oath" commitments to humanitarian objectives. In addition to the specific policies embodied in the "Geneva Declaration", World Medical Association adopted the International Code of Medical Ethics in 1949. Ethical requirements are framed by the duties of doctors: 1) the duties of doctors in general; (2) the duties of doctors with respect to the patients; (3) the duties of doctors with respect to the colleagues. ("WMA Declaration of Geneva", n.d.) "Declaration of Helsinki" - Medical Research Involving Human Subjects was adopted in 1964. ${ }^{1}$ The Helsinki Declaration is an exposure to the ethical principles governing medical research involving human subjects, including research on identifiable human material and personal data. The Act reiterates general ethical principles regarding to the risks, duties and benefits; groups and vulnerable people; scientific requirements and research protocols; ethics committees of research; privacy and confidentiality; informed consent; the placebo effect; post-study provisions; recording the research, publishing and disseminating the results; ineffective interventions in clinical practice. The "Tokyo Declaration" was adopted in 1975 and included guidelines for doctors on torture and other cruel, inhuman or degrading treatment for detention and imprisonment. Starting in 2016, the "Helsinki Declaration" is complemented by the "Taipei Declaration", which contains ethical considerations regarding health databases and bio-banks. The "Lisbon Declaration" on patient rights is adopted in 1981. In 2016 was adopted the "Declaration on Cyber Attacks on Health and Other Critical Infrastructures". Also, World Medical Association have started to involve in shaping the current ethical framework by initiating curriculum development and development programs and adapting it to scientific timeliness. Major activities are made available for knowledge of ethics in medicine: a medical ethics course (World Medical Association, n.d.).

\footnotetext{
${ }^{1}$ The initial version of the Helsinki Declaration remains with only historical significance.
} 
An significant document in the history of human rights, with practical consequences in ethical management regulation is the Universal Declaration of Human Rights proclaimed by the United Nations General Assembly in Paris on December 10, 1948 (General Assembly Resolution 217 A). The Declaration establishes for the first time that fundamental human rights are indivisible and universal. The United Nations has advocated a common ideal for the reaffirmation of the faith of all nations to protect human dignity, freedom, equality and solidarity, social progress and a better quality of life: "All human beings are born free and equal in dignity and in rights. They are endowed with reason and conscience and must behave towards one another in the spirit of brotherhood." ("History of the United Nations", n.d.). In February 2001, Romania ratified the European Convention for the Protection of Human Rights and Dignity of the Human Being in Biology and Medicine Applications and the Convention on Human Rights and Biomedicine (Oviedo Convention). The need to regulate and research medical ethics has expanded in Romania, along with alignment with EU Directives. The ethics bodies set up aim to ensure compliance with patients' ethical rules and to protect individuals involved in the medical act from possible deviations from ethical conduct. Starting with the years of pre-accession to the European Union, Romania ratified treaties and ranks European directives by starting to adapt the national legislation to the European ethical practice in medicine.

After the proclamation and adoption of the Universal Declaration of Human Rights, the main attributions of The World Health Organization (WHO) are in developing good practice guides and ethical management tools in medical interventions ("Global health ethics", n.d.).

Other organizations that contribute to the world's history of a good medical practice are represented by international entities that have leaned on ethical issues. In support of guidelines for ethical compliance, these entities state their concerns by developing requirements that address the various key areas of the ethical framework of medical practice. The Council for International Organizations of Medical Sciences (CIOMS) have participated to developing the "Principles of Medical Ethics relevant to the protection of prisoners against torture" (1983), "International Ethical Evaluation Guidelines for Epidemiological Studies" (1991), or "International Ethics Directives for Biomedical Research involving Human Subjects" (1993) (CIOMS, 2016). 


\section{National context and others connected treaties}

Romania, like other East-European countries, has not been isolated from the ethical consequences of scientific progress in the context of joining the European Union and the military alliances (North Atlantic Treaty Organization). In this context, the Romanian state pursued the application of the results of the implementation of good medical practices, including in military medicine. By adhering to the rigor of internationally ethical rules, Romania has begun building a legal framework for good medical practice. New medical therapies and conditions for the provision of medical services in armed conflicts require ethical regulations to protect of the patients and technical operators who handle equipment and substances whose security requires long-term testing. The first references to ethical concerns have emerged in Romania in the 1990s. The first ethics controlling body was the "Bioethics Committee" of the Academy of Medical Sciences, a public institution of national interest in the field of medical research and pharmaceutical research, academic consecration, subordinated to the Ministry of Health. The coordinator of the "Bioethics Committee," led by Academician physician Constantin Maximilian (1990), gave bioethics a special meaning: "Bioethics is a meeting point of all those who follow human destiny under the pressure of science." (CNBMDM, n.d.).

The most relevant international treaty on human rights issue by United Nations which protect patients' health rights and ethical conduct of medical military personnel is "Principles of Medical Ethics relevant to the Role of Health Personnel, particularly Physicians, in the Protection of Prisoners and Detainees against Torture and Other Cruel, Inhuman or Degrading Treatment or Punishment" (OHCHR, n.d.). There are ten human rights treaty bodies that monitor implementation of the core international human rights treaties: Committee on the Elimination of Racial Discrimination (CERD); Committee on Economic, Social and Cultural Rights (CESCR); Human Rights Committee (CCPR); Committee on the Elimination of Discrimination against Women (CEDAW); Committee against Torture (CAT); Committee on the Rights of the Child (CRC); Committee on Migrant Workers (CMW); Subcommittee on Prevention of Torture (SPT); Committee on the Rights of Persons with Disabilities (CRPD); Committee on Enforced Disappearances (CED) (Centrul pentru Politici şi Servicii de Sănătate, 2015).

The need to ethics management regulate has expanded in Romania once to the military political alliance of the states of Europe and North America, NATO and have progressed during the pre-accession period to the 
European Union. Ethical management is still in the process of reforming by testing ethical control tools of medical practice. At the level of the military medical system, the application of ethical control mechanisms has a progressive impact. Although institutional regulations in the ethics control are the same as those of civilian medical units, the specificity of the situations presented may require the development of customized ethical control tools, which would give rise to a personalized ethical management. The key mechanisms of ethical management identified in Romanian medical practice are ethical regulation, informed consent, ethics incidents assessment body - ethics counselling and ethics training programs. At institutional level, the medical units have set an ethics controlling body, called the Ethical Council.

\section{The concept of Ethics management}

Institutional ethics managing involves controlling all the moral aspects of an organization's life. All management systems include certain ethical elements that serve the medical personnel and are necessary for a good performance of the medical care. These institutional elements significantly influence medical management, are interconnected and function under a dynamic determined by the complexity of the ethical issues. Depending on the medical specializations, the institutional dimension, the location or the level of implementation of a moral standard, one can consider various sets of ethical tools for building an ethics management system. Thus, ethics management is the system of activities and measures aiming at the institutional organization of ethics for the creation of organizations with integrity (Mureşan, 2009). Because the concept of ethics management system involves extensive discussions on various levels, we will summarize a brief description of the meaning we ascribe to this notion. Ethical control mechanisms and ethical debates are subordinated to the performance of medical care and the patient's interest. This ethics management system, including values and moral principles, ensures an ethical organizational climate. The most well-known instruments, which are also to be implemented in the medical-military management system and which could establish an ethics management system are: ethical regulations, informed consent, ethics council and ethical training programs. These tools are considered ethics control mechanisms because they can operate intrinsically and ethically control the military medical practice. On the other hand, building the ethical climate and the integrity of an organization, focusing on promoting moral responsibility and placing the patient's interest 
above the individual and institutional interest requires time, resources and willingness, and does not exclude the appearance of ethical problems. Such conflicts that could affect the ethical climate are the central focus of the ethics council's work.

The process of building the ethical climate has been analysed in the literature. For example, there were described the ethical reforming directions, also the main factors of influences to ethical climate at organizational level and the difficulties in implementing the ethical control mechanisms for organizational integrity. For Ronald Jeurissen, the set of strategies for the implementation of ethics management appears in the form of: - ethics approach based on complying with the rules of ethical codes; establishing an ethical standard based on moral values; - optimizing the moral relationship by approaching a dialogue with external stakeholders: patients, relatives, community; - social dialogue, by involving the community in controversial ethical issues. By this latter strategy, the entire community is responsible for solving the ethical issues under debate (Mureşan, 2009, pp. 36-42). Additionally, Donald Menzel proposes some other strategies to project the ethical dimension at organizational level: (1) scandal is the most frequent triggering factor of ethical reform, (2) ethical issues and regulating efforts are not localized, they extend at international level and are generalized, (3) ethical intervention at organizational level is not achieved by a single strategy, but rather by a continuous process of improving the ethical climate, (4) strict compliance with the legislative rules and excessive formalization of decisions are insufficient to ensure an ethical climate and can even cause ethical rules and moral principles to be ignored, and (5) there is no unanimously accepted grid for the validation of institutional integrity or a management tool that would guarantee an ethical climate (Menzel, 2007). For the purpose of building an ethical climate, we will consider a structural dynamic of the ethics management system. Thus, the toolset available for ethics management, which could be used to build an ethical climate (organizations of integrity) is identified by Donald Menzel in the following elements: - a morally exemplary management team; - practicing ethical training within the organizations; - ethics codes; - professional oaths; ethical audit; - human resources management, based on ethical criteria; moral counsellors. The vision of Valentin Mureşan over a possible scheme of an ethics management system could include: - the Ethics bureau (a technical office that guides and controls the entire ethics management process and provides an annual report to higher authorities); - the Ethics committee (it has an interdisciplinary component; its purpose is to continuously optimize the ethics code and provide moral counselling to the 
management on major and novel issues; - the Ombudsman (receives complaints or requests from moral counselling and tries to resolve disputes by mediating contacts with the services about which such complaints are made; counsels persons who have conscience issues); - the Ethics hotline (Mureşan, 2009, p. 147). All these tools form the control mechanisms and complement each other in building an ethics management system that ensures an ethical climate.

The administration of ethics involves the ethical requirements, fit to the particularities of military medical practice. A good ethical management in medical practice demand an architecture based on set of ethical tools, available to medical practice, and the integration of the functions of its. A successful ethical management system is designed on a set of rules and the moral routes that prescribe the moral judgments of the reported incidents. The moral routes are related to ethical norms and the role of the ethics controlling body. The results of analysing of the ethical incidents depend on existing of the rules. For example, the members of the ethics controlling body take in consideration the dispositions of the ethical norms to determine relevant rules (Mureşan, 2013). The relevant rules are prescribing into the set of ethical principles (Beauchamp \& Childress, 2009), all applicable normative acts, and previous audit reports made to assess the performance of the medical practice.

\section{A model of ethics management system}

Considering this architectural variability of the ethics management system and taking into account the legal regulations on ensuring the ethical climate in medical practice, we can determine the toolset that is applicable in military hospitals: (1) ethical regulations by the ethical and deontological code at institutional level, at professional college levels and the ethical standard established through hospital performance evaluation chart; (2) the ethics controlling body (e.g. Ethical Council), established at the territorial military hospital level; (3) audit of the ethical standard through the hospital accreditation mechanism, (4) the patient feedback mechanism and (5) the Ethics Yearbook ${ }^{2}$. The functioning of military structures, including medical ones, relies to a great extent on a pyramid organization, very well-articulated chain of command, with the commander having the authority to guide all forces in order to achieve the goals of the organization. This balance of power - on the one hand medical deontology and the perspective of the

\footnotetext{
2 These ethical instruments are design by the norms of setting up the Ethical Council in Romania (Order of Health Minister no. 1501/2016 and 1502/2016).
} 
liberal profession, and on the other hand formalism and institutional rigidity -, if not coordinated, can generated tensions on the specialist. At the same time, the similarities between these two systems: rigor, dignified conduct, preservation of the image of the organization, the common good and helping others can synergize to create the prerequisites for the implementation of ethics management.

\section{The institutionalization of ethics through the Ethics Council}

\section{The background of military medical units}

Military medical units refer to structures created to provide medical assistance to persons related to military status, aggrieved by armed conflicts, research, peacetime or armed conflict, fixed or mobile, permanent or temporary. Military medicine, as well as civilian medicine, has its roots in the ancient Greek times. The Romans imported from Greece, to a great extent, the medical abilities to care for the wounded. For them, the motivation of health care was not purely humanitarian. They recognize medical necessity in military. The first form of organized medical care occurs around the '100s. The places where they were cared and treated are the major contribution of Rome to medicine. The hospital system naturally appeared for the treatment of wounded soldiers (infirmary). The purpose of these settlements was to preserve the integrity of the Roman legions. Probably, in the provinces, the private institutions that were supposed to take care of the Romans turned, with priority, into subsidized public hospitals (Singer, 1928, pp. 36-60). The link between the former medical care units and current military ones is obvious. The purpose of their operation is to improve the health of the wounded.

Military medical units include all medical facilities: transport services, blood transfusion services, investigative services, etc. ${ }^{3}$ In Romania, medical assistance is insurances by specialized, interoperable "logistics structures" able to achieve a rapid modular adaptation with a role in supporting and preparing military operations for participating in joint actions with the army structures of the member of $\mathrm{NATO}^{4}$. The regulation of these military logistics structures and action protocols consider the mobility and adaptability to military needs for medical interventions in public hospitals, the territorial health network or in the sanitary units in theatres of operations

\footnotetext{
${ }^{3}$ Protocol additional 1 to Geneva Convents, 12-08-1949 on the Protection of Victims of International Armed Conflict, Art. 8.

${ }^{4}$ Ministry of Defence. "Order no. 36/2008 for the approval of the Joint Operations

Logistics Regulation. Regulation of the combined operations logistics"
} 
(Săndulescu, 2007). Although military medical staff are working in complex cultural environments, which often contrasts with civilian life, and military medicine structures are modular, adapted to specific cases, ${ }^{5}$ the role of ethics bodies could be similar in civilian hospitals with the territorial military hospitals or the units of medical campaign from theatres of operations.

\section{The background of ethical regulation for the military medicine}

Due to the military profile of military medical units, military hospitals or medical campaign units in theatres of operations determines a particularity of ethics management and generates an institutional approach distinct from that of civilian units. While there are similar issues in ethical regulations, the double function of medical personnel, the medical and the military one, confers an institutional particularity. The regulations and organization of military hospitals are tailored to both peacetime and wartime missions. To all armed conflicts apply to the international humanitarian law $(\mathrm{IHL})^{6}$ or the "law of war" which covers all participants in the military conflict. There is also a substantial set of rules binding on all states and parties to a conflict. The working group of International Committee of the Red Cross to amend Article 77 (1) of Additional Protocol I to the Geneva Convention have tried to set and regulate some principles, grouped in three categories. (1) Principles on the Effective Prevention and Investigation of Extra-Legal, Arbitrary and Summary Executions. Governments shall prohibit orders from superior officers or public authorities authorizing or inciting other persons to carry out any such extra-legal, arbitrary or summary executions. All persons shall have the right and the duty to defy such orders. Training of law enforcement officials shall emphasize the above provisions. (2) Basic Principles on the Use of Force and Firearms by Law Enforcement Officials. Governments and law enforcement agencies shall ensure that no criminal or disciplinary sanction is imposed on law enforcement officials who, in compliance with the Code of Conduct for Law Enforcement Officials and these basic principles, refuse to carry out an order to use force and firearms, or who report such use by other officials. (3) UN Declaration on Enforced Disappearance. No order or instruction from any public authority, civilian, military or other, may be invoked to justify an enforced

\footnotetext{
${ }^{5}$ See "Regulation of the combined operations logistics" and the incidence of diseases / injuries caused by armed attacks (Order no. 36/2008).

${ }^{6} \mathrm{IHL}$ is a set of rules that try to limit the effects of armed conflicts, protect people who do not participate in, or no longer participate in hostilities, and restrict war means and methods. An exposition of the rules can be found on the page International Committee of the Red Cross / https://www.icrc.org/en/war-and-law.
} 
disappearance. Any person receiving such an order or instruction shall have the right and duty not to obey it (International Committee of the Red Cross, n.d.). According to these recommendations, United Nations formulate relevant standards and law enforcement agencies are advised to incorporate rules, regulations and ethical codes. The main documents are The Code of Conduct for Law Enforcement (CCLEO) and the Basic Principles on the Use of Force and Firearms by Law Enforcement Officials (BPUFF) (International Committee of the Red Cross, 2014). In the system of rules imposed on military personnel, there are three powerful direction to approaching of activity of military medical personnel, distinct from nonmedical military personnel only, adequate with their debts: involving in act of war, involving in actions which cause damages to prisoners, involving in procedure for restraining a prisoner or detainee. (1) The health personnel, particularly physicians, do not engage, actively or passively, in acts of warfare or derivate acts, as incitement to or attempts to commit torture or other cruel, inhuman or degrading treatment. They only can use weapons to protect their patients. (2) The health personnel, particularly physicians do not involve in action to cause damages to prisoners. They are not allowed to apply knowledge and skills in order to assist in the interrogation of prisoners and detainees in a manner that may adversely affect the physical or mental health or condition of such prisoners and which is not in accordance with the relevant international instruments. They are not allowed to certify, or to participate in the certification of, the fitness of prisoners or detainees for any form of treatment or punishment that may adversely affect their physical or mental health and which is not in accordance with the relevant international instruments, or to participate in any way in the infliction of any such treatment or punishment which is not in accordance with the relevant international instruments. (3) the health personnel, particularly physicians do not participate in any procedure for restraining a prisoner or detainee unless such a procedure is determined in accordance with purely medical criteria as being necessary for the protection of the physical or mental health or the safety of the prisoner or detainee himself, of his fellow prisoners or detainees, or of his guardians, and presents no hazard to his physical or mental health (General Assembly of the United Nations, 1982).

If we relate to the set of ethical tools applicable to institutional ethical management, we recognize in the Ethical Council the structure that identifies moral failing. The members of the Ethical Council recommend solutions to avoid possible deviations from ethics and establishing the morality of acts undertaken by military ethics and guiding the ethical behaviour of medical-military personnel. From examining the available 
regulations applicable to military medicine, there is a "medical command structure" which retrieve the role of identifying moral breaches, recommending solutions to avoid possible deviations from ethics, establishing the morality of acts performed by military doctors and guiding ethical behaviour (British Medical Association, 2012).

Nevertheless, the regulations on ethics management in hospitals are the same for both military and civilian hospitals. In November 2003, at the World Health Assembly, the World Health Organization (WHO) proposed to establish an international alliance, the International Alliance for Patient Safety, having the purpose of improving the safety of medical care in all member states. Additionally, the alliance proposes a control mechanism, tailored for global or multiple implementation, to improve the effectiveness of medical care. In this respect, the organization called the development and promotion of norms and global standards on patient, of evidence-based policies and the development of mechanisms for international recognition of excellence in patient safety, the encouragement of research in this field and the support of member states in key areas. With these measures, the expectations of the $\mathrm{WHO}$ are reflected in improving patient safety, reducing the risk of harm, better results in health care, improved patient experience and lower costs (WHO, 2017).

While progress has been noted in the development of specific policies on patient safety in the member states, in the second report of the Commission to the Council of the European Union on the implementation of the Council Recommendation 2009/C 151/01 on patient safety, including the prevention and control of healthcare associated infections, the European Commission recognizes that it is difficult to integrate the results of nonunitary reporting, identifying uneven progress in the European Union. There are issues in the understanding of standards and guidelines. The manner of reporting varies from one country to another: "Some countries report the existence of specific standards for a type of adverse event, others on quality management systems, and others use reporting and learning systems as examples" (European Commission, 2013).

\section{Ethics Council}

The architecture of the ethics system of military medical practice is determined by military operations. Thus, in peacetime or in armed conflict, providing medical care in military units organized as military public hospitals, under the aegis of public health authorities and military authorities or in medical campaign units in theatres of operations, the treatment of 
chronic diseases or affection generated only in military interventions ${ }^{7}$, are determining factors for a customized ethical management. Military medical personnel are given a specific ethical infrastructure, an ethical standard based on values and principles (Mehlman \& Corley, 2015). As we have indicated, the ethical structure dealing with these ethical conflicts could be take form of The Ethical Council, the Ethics Bureau, The Ethics Committee or a person with role of the Ethical Counselling. All these structures, individual or not, have the role of applying ethical management system tools. There are three board areas of ethics controlling body in order to providing ethical medical practice in medical units: the consolidate the trust policy and guidelines around patient care, facilitating ethics education of health professionals within the trust, and giving advice to clinicians on individual cases. There is also the engagement for innovative work in each of these three functions (Slowther, Johnston, Goodall \& Hope, 2004).

\section{Developing the ethical structures}

During Romania's European Union pre-accession period, healthcare Romanian experts have described the need to implement ethics structures to provide ethics control for medical practice. After the reform of healthcare was initiated in $2006,{ }^{8}$ a makeshift form of an ethics management system appears, which established the Ethics Council in public hospitals (Ministry of Health, 2006). The role of this Council is to assess the cases of violation of conduct rules in the patient's relationship with healthcare or auxiliary staff, behavioural rules and discipline in public hospitals, to verify compliance with patients' rights and to notify the competent bodies in case of violation of the regulations stipulated in the medical deontology code, the law on patients' rights, as well as the rules of professional conduct. The Ethics Council did not function in this version. The efforts to implement a form of ethics management continued from 2008 to 2010. In 2009, the Association for the Implementation of Democracy through the National Integrity Centre, proposed to the Ministry of Health to establish an integrity structure that would prevent misconduct in the healthcare system. By the project "Good Governance by Integrity and Responsibility in the Romanian Healthcare System", the Ministry of Health answered the requirements of the European Commission's Cooperation and Verification Mechanism. The

\footnotetext{
${ }^{7}$ Military medical care considered to be the procedures generated by "ADMCBRN attacks" (chemical, biological, radiological, nuclear weapons of mass destruction), "EADA effects" (emissions other than attack), arson and ammunition.

8 The health reform was initiated by adopted the Law no. 95/2006.
} 
overall goal of the project was to ensure a climate of integrity and responsibility in the healthcare system. The Ministry of Health's intention was to create a framework for the application of coherent policies to promote integrity in the healthcare system, by supporting the process of sector decentralization and identifying measures intended to increase responsibility in spending public funds. A new structure is introduced in the organizational chart of the Ministry of Health: "the directorate for control and integrity"'.

The European Commission's Report on the Cooperation and Verification Mechanism of July 2011 mentioned that the result of the initiative to improve integrity and responsibility in the healthcare system "is not visible yet" (Ministry of Health, n.d.). The project has major importance in the ethical architecture of the medical service system, because its fundamental analysis includes the identification of ethics control mechanisms. It remains to be seen whether the structures thus created will be functional and will bring the expected results: ensuring quality healthcare in an ethical environment. In 2015, another Order of the Ministry of Health is published (Ministry of Health, 2015), approving the structure and attributions of the Ethics Council. ${ }^{10}$. The functional framework of the Council changes and become structured as follows: elected representatives of the hospital's body (3), elected representatives of hospital nurses (2), legal advisor or a representative of the hospital's functional team, with higher education, appointed by the healthcare unit management (1) and elected representative of the patients' associations (1). Maintaining this order for only 12 months was not enough for this ethics structure to become operational. The functioning of the Ethics Council in public hospitals is currently regulated by new norms (Ministry of Health, 2016). The Order specifies the meaning of the terms used in the ethical assessment, the structure of the Ethics Council ${ }^{11}$ and the selection criteria for the elected

\footnotetext{
9 "The Directorate for control and integrity” is established by Government Decisions (GD), amending GD 144/2010 on the organization and functioning of the Ministry of Health (amendments to GD 144/2010 were made with GD 755/2011 - establishing the Integrity Department; GD 37/2017 - confirming the status of the department, but becoming "integrity service"; GD 357/2017 - confirming the status of the department, but becoming "directorate for control and integrity".

10 The text of the order is the result of the efforts made by experts who contributed to the above-mentioned project, which was implemented between November 2011 and November 2013 / http://www.integritate.ms.ro/.

11 The structure of the Ethics Council varies according to the status of the hospital: clinical hospital, university hospital and institute $(7$ members: 1 elected representative of the hospital's doctors, from the clinical integration personnel, 3 elected representatives of the hospital's
} 
representative of the patients' associations. It is useful to mention the meaning ascribed by the order to the notions of Ethics Council <article 1, d)> and Ethics Yearbook <article 1, h) and i) > . According to article 1 of the order, the Ethics Council is the "moral authority forum established in hospitals, in order to guarantee the valorisation of the moral and deontological principles within the healthcare system. The Ethics Council fosters integrity in the hospital and issues opinions and decisions regarding medical and organizational ethics", and the Ethics Yearbook is "the compendium of ethical opinions and decisions of the Ethics Council", which focuses on the experience in ethics, used to initiate prevention activities at hospital and national level. For the functioning of the Ethics Council, access is granted to the legal advisor, who has the exclusive role to provide legal support for the Council, as well as the Secretary of the Ethics Council, appointed by decision of the manager, to support the activities of the Council, without being a member with the right to vote in decision making. Council members, the legal advisor and the secretary of the Council must prove good moral reputation and the absence of criminal record. Training in ethics and integrity is recommended and should be given priority.

\section{The Council's function}

The Council's function is to provide ethics control for medical practice by: (1) analysing the ethical risk; (2) preparing prevention measures and (3) analysing the specific causes of the complaints with ethical impact. All three goals result in an institutional ethical report. The Ethics Council is an ethics control mechanism intended to solve cases with ethical impact, by decisions resulting in recommendations or findings. Thus, proactive decisions take the form of recommendations for future action, based on ethical risk analyses estimation of potential moral damage. On the other hand, reactive decisions are formulated following actions with ethical impact on the patient, employees or institution. The ethical standard, as represented by the applicable regulations, appears to be based on a set of ethical principles, structured as follows: (1) the principle of respect for the patient's

doctors, other than the clinical integration personnel, 2 elected representatives of the medical nurses in the hospital, 1 elected representative of the patients' associations) or other public healthcare units ( 7 members: 4 elected representatives of the hospital's doctors, 2 elected representatives of the medical nurses in the hospital, 1 elected representative of the patients' associations) or hospitals with less than 20 medical personnel (5 members: 2 elected representatives of the hospital's doctors, 2 elected representatives of the medical nurses in the hospital, 1 elected representative of the patients' associations). 
autonomy; (2) the principle of equity and social justice and patients' rights; (3) the principle of beneficence and doing no harm. These principles are part of the evaluation checklist of military medical units, for the accreditation of hospitals. ${ }^{12}$ Accreditation gives the guarantee of healthcare services under safe conditions for the patient and the personnel, by preserving personal data, respect for the environment and for the needs of the community.

The process of standardization is also distinguished by a centralization system for cases resolved by Ethics Councils - the Ethics Yearbook $^{13}$. Some data regarding the activities of Ethics Councils are published on the secured IT platform of the patient feedback mechanism, developed and maintained by the Special Telecommunications Service (STS). Currently, no data are found in the military healthcare network - territorial hospitals (“Activitatea Consiliilor Etice din unitatile sanitare publice - 2017”, n.d.). The objective is to improve medical care by evaluating patient experience, the transparency of the aggregated results of the evaluation, the identification and dissemination of the good practice models (Ministry of Health, 2016). The Ethics Yearbook also includes a component on the management of complaints related to ethics and integrity incidents that have taken place in the public hospital.

\section{The Issues of Ethics in Military Medicine. Specific Elements and Difficulties}

In the military territorial hospitals and in the medical campaign units in the theatres of operations, ethical incidence has a constant component: impairing the decision-making freedom of medical staff. The critical incidents in military ethics are related to Dual Loyalty and Human Rights in Professional Practice (DLHR) (International Dual Loyalty Working Group, 2002). Dual loyalty conflict is defined as "clinical role conflict between professional duties to a patient and obligations, express or implied, real or perceived, to the interests of a third party such as an employer, insurer or the state." (Singh, 2003). Strict ethical control requires decision-making, based

\footnotetext{
${ }^{12}$ In order to reach a competitive level in medical healthcare, military hospitals are also evaluated by national accreditation bodies, the National Authority for Healthcare Quality Management (A.N.M.C.S.) - http://data.gov.ro/dataset/lista-spitalelorpublice/resource/0f076462-a72e-4b2d-ab24-1df4c7f26f2f?view id=9be4cba2-4eb6-484c9fa8-27deb60b1bdc and http://anmcs.gov.ro/web/wp-content/uploads/2014/12/Listaspitale-acreditate-ciclul-I.pdf.

${ }^{13}$ According to the definition given in the Ministry of Health of Romania, "the Ethics Yearbook" is the collection of ethical opinions and decisions of a hospital's Ethics Council, concentrating the experience in ethics, used to initiate prevention activities in that unit.
} 
on ethical analysis and decision-making. Even though the institutional ethical infrastructure does not include the whole arsenal of ethical tools, the existence of a competent ethical structure that provides analytical solutions and decision-making criteria proves its usefulness in militant medical practice. There is a wide range of ethical incidents that can be exploited to test ethical tools, due to extreme situations of the military conflict. These exceptional circumstances shape complex ethical issues, generated mainly by the double function of medical personnel: the tension that arises between two duties, of a physician and of a military framework, in relation with that person's individual principles. Only through rigorous ethical control can we assess the ethical incidence in military medicine and its impact on human dignity, either on patients or on practitioners. Ethical accountability in military medical practice is extensive, by the impact on the professional freedom of decision-makers. The ethical issues we have dealt with concerns the decision-making autonomy of medical personnel in military conflicts, the limitation of professional independence, the deficiency of medical personnel training related to the ethical specific military medical activity, the alteration of the confidential nature of the medical-patient relationship. The ethical incidence in military medicine is ample, both in the provision of medical care by treating wounds of war, for combat personnel in theatres of operations, civilian non-combatants, and in dealing with prisoners who may set a threat to the security and integrity of the state. In this article, the assessment of ethical incidence is seen as an instrument of capitalizing on the potential of an ethical management system.

To illustrate the control function of the ethics controlling body - e.g. Ethics Council, we will refer to a case from military medicine that reflects the possible dilemmas faced by medical personnel. While the example belongs to military medicine, it could be easily extrapolated to civilian medicine: the ethical dilemma presented could essentially occur in any medical care unit.

\section{How would the Guantanamo Bay case be outline in ethical reports?}

In 2004, the American press brought to public attention the case of a person that was both a doctor and soldier. Thus, a member of the military who were in the same time a nurse with rank of lieutenant, with 18 years of service, worked in the prison of Guantanamo Bay. For ethical reasons, he refused to take part in the forced feeding of prisoners who were on a hunger strike. While the nurse - whose name remained undisclosed - based his decision on professional ethics, the refusal to obey orders caused him a lot of trouble: he was withdrawn from Guantanamo Bay, he was threatened 
with bringing before the Court Martial, administrative investigation and possible discharge from the Navy. After approximately two years of trials, the nurse was fully reinstated, a decision that was praised by the American Nurses Association, who had been actively supporting him all this time (Rosenberg, 2016).

This example is eloquent for the dual function of military medical personnel and the specific difficulties faced by those professionals. Such difficulties are mentioned in an UK report on military medical ethics:

Physicians of the armed forces work in closed hierarchical command structures. As members of the army, it is possible for them to identify with the unit or service to which they belong and feel strong loyalty towards it. At the same time, their professional obligations as physicians require them to place their ethical duty to their patients above their responsibility and loyalty to the army. These factors can trigger conflicts of interest for military doctors (BMA, n.d., p. 5).

In this case, the conflict can be formulated as follows: do I protect my patient's interests or the interests of the unit I belong to? Considering that military doctors work in national healthcare units, under very similar conditions to the civilian environment, but may also perform missions in theatres of operations in areas of armed conflict, many other unexpected circumstances and problems with unclear solutions may occur during their daily work. For instance, how can informed consent be obtained under a linguistic or cultural barrier where the native population does not cooperate or understand? How can objectively triage the wounded in the conflict areas, where it is presumed there is a hostile population and arrives at the hospital at the same time with comrade soldiers that are close to the physician? Should doctor-patient privilege be kept when a hierarchical superior requests information? Which are the limits for a detainee's treatment: is it acceptable for a physician to examine them to be declared able to withstand questioning / imprisonment / punishment? How can the civilian population be treated properly with limited resources and under sub-standard conditions that are typical for conflict areas? (BMA, n.d., p. 5). In states with a history of involvement in international operations and with a tradition in developing and implementing an ethical infrastructure in national military organizations, such questions have a fundamental importance and are widely debated, for the purpose of providing ethical guidance to military doctors facing such problems.

Similar questions have been thoroughly analysed in a comprehensive report on the ethical regulations for military medical personnel, issued by the US Defense Health Board, following a request to resolve two issues 
(Defense Health Board, 2015) of ethical nature that are specific to military medical activities:

"How can military medical personnel balance their obligations towards patients and their obligations as military officers to help their commanders to maintain military readiness?"

"How much freedom should military medical personnel have, in order to refuse participation in medical procedures or to request permission to be absent from military operations to which they have ethical reservations or ethical disagreement?"

In order to find the adequate solutions to such questions, the report covers in detail the entire spectrum of ethical issues in the military medical activity and provides theoretical background principles extracted both from medical ethics and military ethics. Finally, the report makes recommendations for an ethical infrastructure for military medical units, consistent with the particularity ethical issues facing the active personnel and the deficiencies in the system. The main recommendations involved the implementation, by the Ministry of Defense, of policies and guidelines guaranteeing that the first ethical obligation of a military doctor is towards the patient (Defense Health Board, 2015, p. 18), the formulation and implementation of a specific ethics code for military medicine, the implementation in the military medical structures of ethics boards and ethics advisory services (including the appointment of an expert in medical ethics for each unit), specific training of military doctors on the confidentiality of information within the context of hierarchical responsibility and the applicable exceptions, giving a privileged status to military doctors in the relationship of confidentiality with the patient (a similar status to that of a priest or a lawyer) (Defense Health Board, 2015, p. 39). Additionally, it was recommended that the Ministry of Defense create an online portal for medical ethics and specific programs for initial and continuing training in military medical ethics.

The fact that specific solutions have been proposed for ethics management in military medicine is an argument in favour of the idea that ethics management is operational only to the extent that it is adjusted to the specific needs of medical units. In other words, even if a standardized ethics infrastructure were to be implemented, in this form it may not have the necessary means to make decisions under special circumstances.

\section{Are there enough tools to apply ethical control mechanisms?}

Let us consider, for example, the above-mentioned case. From the information that we had access to, the military medical professional did not receive ethical advises from an expert, and his action was not subjected to 
institutional ethical evaluation. Additionally, by removing the specific circumstances in which the case occurred, the refusal of the medical professional to attend to a patient for ethical reasons acquires a universal value that is easy to imagine on any setting. What would have been the outcome of the case had it been subjected to ethical evaluation and not to disciplinary action? Could we respond to this situation by activating the control mechanisms regulated through the ethics controlling body? In order to test the functioning of the Ethics Council as regulated in Romania, we have applied the available tools for an ethical analysis of the case and for the establishment of an ethical reasoning. Could the ethical infrastructure of the medical ethical system, as it is known to us, have provided the alternative of an ethical decision to the detriment of disciplinary measures?

The ethical infrastructure has the function to control immoral behaviours in the medical practice by: (1) ethical risk analysis; (2) preparing prevention measures, and (3) analysing the specific causes of complaints with ethical impact. A first phase in the activity of the Ethics Council is based on establishing formal requirements: whether the controversial intervention of medical staff is regulated or whether the intervention it is a proactive or a reactive assessment. The conclusion of Ethics Council has the prevention feature if ethical incident repeat. In a second phase, it is necessary to identify the ethical impact. There are important to set the methodology of decision-making. For example, in this case, Ethics Council has the perspective of principlism. Based on common morality, Beauchamp and Childress, projected a framework for ethical evaluation, set on the four basic rules of ethical principles (1) autonomy (free-will or agency), (2) beneficence (do good), (3) non-maleficence (do no harm) and (4) justice (social distribution of benefits and burdens) (Beauchamp \& Childress, 2009). The conflicts created between the principles must be evaluated by members of members of the Ethics Council. The third phase consists in the decisionmaking, to providing a justified solution that is not prone to contestation. Council members should give medical professionals informed solutions on whether an action is ethical.

Lacking other procedures that would give council members support on ethical decisions, we can only assume that they would use their own conscience, relying on informally obtained ethical competences. However, one's own experience is not enough to ethically justified measures about to be taken or that were taken, when the conduct of military medical professionals can lead to major consequences. Additionally, exactly due to this lack of methodology, we cannot deduce what decision the council members would have made, and so the solution becomes arbitrary. 
However, regardless of the solution that the Ethics Council would have proposed, we feel that the case belongs exclusively to the jurisdiction of an ethics controlling body. Disciplinary review is not required, unless the previous stages of appeal to ethics bodies were omitted. The Ethics Council decision takes the form of a recommendation and ascertains whether the intervention of the medical staff was ethical in accordance with the applicable rules. Cases that balance ethical principles should not be subjected to the administrative circuits, as this would limit the possibility to decide in accordance with one's moral conscience and the principles assimilated from ethics training programs. Furthermore, such a decision of the Ethics Council lacks weight if it is not guaranteed by the management of the medical unit concerned. The nurse from the discussed case would have not had a favourable decision from the Ethics Council if it was not supported by the hierarchic superiors. From this perspective, the impartiality of the Ethics Council can function until the time of the decision, as it is subject to approval by the management of the unit.

Such possible shortcomings of the Ethics Council may be obvious when its functioning is tested theoretically. However, similar obstacles have been identified in practice, in the Romanian healthcare system, in difficulties encountered by members of the Ethics Council. Thus, the interviewed members of the Ethics Council ${ }^{14}$ (Marinescu, 2018) complained about the lack of guarantees for their independent decision making. Administrative subordination to the hospital manager and having the cases selected by the manager makes it arguable whether it is possible to avoid conflicts of interests and questions the transparency in the review of the cases. Complaints are centralized administratively by a responsible person appointed by the manager. This involvement of the hospital manager in the process of case selection and redirection through subordinated structure involves a risk in the decision-making process and is neither recommended nor desired by council members. Some cases that reached the agenda of the Ethics Council were resolved urgently, in order to avoid interference from outside the council. The discussions we had with council members confirmed the difficulties they encounter in assessing the cases: there is no

\footnotetext{
${ }^{14}$ In a doctoral project covering, among others, the progress in the implementation of ethics tools, members of the Ethics Council have underlined the most important obstacles to the development of an ethics control mechanism, within the framework of the ethical reform of the healthcare sector. Further data regarding the implementation of the ethics council in hospitals can be found in the research section of the doctoral project Ethics Management in Organizations. Ethics Infrastructure in Medical Services, Adina Marinescu, University of Bucharest, Philosophy School (2018).
} 
methodology or guidelines for case assessment, and ethical competences are not required for members of the Ethics Council, as they review the cases relying on their own system of values and principles and their own experience. The operating framework of Ethics Council and the structure of team is are not representative for the cases with ethical implications. For instance, applicable regulations require a certain structure of the council and omit the representation of other related medical services (pharmacists, psychologists, etc.). According to the legal provisions, being a member in the ethics council is incompatible with the following positions: personnel from outside that healthcare unit, employees and/or contractors of companies that manufacture or distribute medicines, sanitary materials, medical equipment and devices; employees or contractors of service providers with which the hospital has a contractual relationship. The possibility to contract independent external experts or to employ professionals that have the necessary competences to resolve ethical conflicts is thus limited. It is however specified that the "establishment meeting is presided by the most senior elected member" (Ministry of Health, 2016). Considering the lack of ethical training of the Ethics Council members, it is justifying their necessity to identify for the opportunities to exchange experience with other experienced Councils team and obtain the ethical good practice. We have noticed the urgent need of ethical involved persons to be trained in ethical decision-making in medical intervention. They are aware of the importance of the medical act consequences in accordance with ethical principles and they want to respond to their ethics mission as good they can.

Finally, ethics controlling is not a traditional process in Romanian military medical practice. For this reason, it is necessary to raise awareness of the need for ethics in medical practice, of resources for implementation and especially of time and willingness to verify the effectiveness of ethics control measures. For all these considerations on ethical reasoning, the limitations in the application of the Ethics Council's decision confirm the difficulty in implementing the ethics control mechanisms.

\section{Conclusions}

The effects of the specific military context are transposed in the absence of transparency of ethical decisions, limitation of the military personnel's autonomy, or alteration of the confidential nature of the doctorpatient relationship. The dual function of military medical staff provides new insights into the mechanisms of medical-military ethical control. The extreme situations, in which the medical act is carried out by military 
personnel, may justify the suspension or limitation of ethical medical obligations. At the organizational level, medical activity incorporates a management system of ethics. It is designed to ensure good medical practice by informing patients about their rights, by creating and maintaining institutional confidence and by establishing good interaction between healthcare professionals and patients. Military medical practice involves specific ethical particularities, mainly given by the double function of medical professionals. The ethical issues that they face under exceptional circumstances are hard to solve, since the ethics infrastructure is not tailored to the needs of the military service or the specific medical activities.

Within the context of Romania's regulations, the central element of this infrastructure is the Ethics Council. In the absence of development on other tools complementing the function of the ethics council (such as the Ethics Office, ethics counselling, ethics ombudsman), the Council becomes the unique administrator of ethics. However, the current architecture of the Council is not designed to ensure universal solutions for the cases that are identifiable at institutional level. Furthermore, it is possible to identify functional vulnerabilities caused by the absence of a decision-making methodology, by possible administrative interference in ethical decisions and the lack of ethical training for Council members.

Matters of management of ethics in medical military units do not figure prominently on the public agenda. However, ethics management decisions in military medical units are in fact riddled with ethical questions and do have significant impact on patients, military medical staff, and the community. Medical activity is coordinated through standardized practices to ensure the quality of services, patient safe and respect for professional freedom. For a productive ethics management system, it is necessary a resolution strategy of institutional ethical incidents. Each medical military unit accedes to the universal ethical objectives, relates on fundamental ethical principles, and customizes rules and procedures to the circumstances of the cases. In order to obtain a valid ethical solution, it is necessary to set the moral routs, to identify the methodology for ethical decision making and professional staff attends to specific ethical training. The availability of a set of ethical tools is not enough to verify the functions of ethics controlling body. The perspective of the integration of functions assurance a good medical military practice. In this article, we assessed the framework of ethical regulation of the ethical instrument which control medical military practice. There are normative premises for an ethical climate, by available ethical tools of military medical practice, but only the sustained ethical training of medical staff, bringing to the public attention of solved ethically cases and practice 
ethics, could bring success of ethical management in medical military units. Integrated functioning of the ethical tools is the ground of ethics management.

In order to ensure an institutional ethical climate in military medical practice, it is necessary to raise awareness of the specific ethical issues and to create proper structures for the medical military context. Ethical regulation and periodic review of ethical procedures, improvements of professional ethical competences develop the ability to practice ethics.

\section{References}

Beauchamp, T. L., \& Childress, J. F. (2009). Principles of Biomedical Ethics. New York, Oxford: Oxford University Press.

BMA (n.d.). Ethical decision-making for doctors in the armed forces: a tool kit. Guidance from the BMA Medical Ethics Committee and Armed Forces Committee. Retrieved from https://www.bma.org.uk/advice/employment/ethics/armed-forcesethics-toolkit

British Medical Association (2012). Ethical decision-making for doctors in the armed forces: a tool kit. London: BMA House.

Centrul pentru Politici şi Servicii de Sănătate (2015). Drepturile omului in ingrijizrea pacienților: ghid pentru practicieni. Buzău: Alpha MDN.

CIOMS - The Council for International Organizations of Medical Sciences (2016). 2016 International Ethical Guidelines for Health-related Research Involving Humans. Retrieved from http://www.cioms.ch/index.php/2012-06-07-19-16-08/aboutus/bioethics

CNBMDM - Comisia Naţională de Bioetică a Medicamentului şi a Dispozitivelor Medicale (n.d.) Retrieved from http://www.bioetica-medicala.ro/

Defense Health Board (2015). „Ethical Guidelines and Practices for U.S. Military Medical Professionals." report. 03032015.

Ehrenfreund, N. (2007). The Nuremberg Legacy. New York: Palgrave MacMillan ${ }^{\mathrm{TM}}$. p. 149.

European Commission (2013). The Commission's Second Report to the Council on the implementation of Council Recommendation 2009/C 151/01 on patient safety, including the prevention and control of healthcare associated infections.

General Assembly of the United Nations (1982). Resolution 37/194 of 18 December 1982. Principles of Medical Ethics relevant to the Role of Health Personnel, particularly Physicians, in the Protection of Prisoners and Detainees against Torture and Other Cruel, Inhuman or Degrading 
Treatment or Punishment. Retrieved from https://www.ohchr.org/EN/ProfessionalInterest/Pages/MedicalEthics.as px

Guvernul Romaniei (n.d.). Activitatea Consiliilor Etice din unitatile sanitare publice 2017. Retrieved from http://data.gov.ro/dataset (accessed on 1101 , 2018).

International Committee of the Red Cross (ICRC). (2014). To serve and to protect. Human rights and humanitarian law for police and security forces.

Retrieved from https://www.icrc.org/en/publication/0698-serve-andprotect-human-rights-and-humanitarian-law-police-and-security-forces

International Committee of the Red Cross (n.d.). Practice Relating to Rule 154.

Obedience to Superior Orders. Retrieved from https://www.icrc.org/en/warand-law (accessed on 11 01, 2018).

International Dual Loyalty Working Group (2002). Physicians for Human Rights and School of Public Health and Primary Health Care. Dual Loyalty \& Human Rights in Health Professional Practice; Proposed Guidelines \& Institutional Mechanisms. United States of America: University of Cape Town, Health Sciences Faculty.

Marinescu, A. (2018). Ethics Management in Organizations. Ethics Infrastructure in Medical Services. Romania: University of Bucharest, Philosophy School.

Mehlman, M. J., \& Corley, S. O. (2015). A framework for Military Bioethics. Journal of Military Ethics, 13(2015), 331-349.

Menzel, D. (2007). Ethics Management for Public Administrators: building organizations of integrity. London: M.E. Sharpe, Inc.

Ministry of Health (2006). Order no. 1209/2006 approving the members and powers of the Ethics Council functioning in public hospitals, repealed by Order no. 145/2015, in turn repealed by Order no. 1502/2016.

Ministry of Health (2015). Order no. 145/2015 approving the structure and duties of the ethics council functioning in hospitals, currently repealed by Order no. $1502 / 2016$.

Ministry of Health (2016). Order no. 1502/2016 approving the structure and duties of the Ethics Council functioning in public hospitals.

Ministry of Health (n.d.). Retrieved from www.integritate.ms.ro (accessed on 11 01, 2018).

Mureşan, V. (2009). Managementul eticii in organizaţiii. Bucureşti: Universitatea Bucureşti.

Mureşan, V. (2013). An Organization's Moral Topography. Transylvanian Review (Centrul de Studii Transilvane / Centre for Transylvanian Studies) XXII, 1(2013), pp. 33-46. 
OHCHR - Office of the United Nations High Commissioner for Human Rights (n.d.). Universal Human Rights Instruments. Retrieved from https://www.ohchr.org/EN/ProfessionalInterest/Pages/UniversalHuman RightsInstruments.aspx

Order of the Ministry of Defense no. 36/2008 for the approval of the Joint Operations Logistics Regulation. Regulation of the combined operations logistics.

Rosenberg, C. (2016). Navy reinstates nurse who refused to force-feed at Guantánamo. Retrieved from https://www.miamiherald.com/news/nationworld/world/americas/guantanamo/article75398072.html

Săndulescu, M. D. (2007). Posibilităţi privind sprijinul medical în campanie. Revista Forţelor Terestre (Statul Major al Forțelor Terestre), 08(2007), pp. 97-103.

Singer, C. (1928). A Short History of Medicine. Oxford: Oxford University Press.

Singh, J. A. (2003). American physicians and dual loyalty obligations in the "war on terror". BMC Med Ethics, 4(1), pp. 1-10.

Slowther, A., Johnston, C., Goodall, J., \& Hope, T. (2004). Development of clinical ethics committees. The BMJ, 328(7445), pp. 950-952.

United Nations (n.d.). History of the United Nations. Retrieved from http://www.un.org/en/sections/history/history-unitednations/index.html

WHO - World Health Organization (2017). Patient Safety: Making health care safer. Retrieved from: https://apps.who.int/iris/bitstream/handle/10665/255507/WHO-HIS$\underline{\text { SDS-2017.11-eng.pdf? sequence }=1}$

World Health Organization - WHO (n.d.). Global health ethics. Retrieved from http://www.who.int/ethics/en/ (accessed on 2 20, 2017).

World Medical Association - WMA (n.d.) Retrieved from www.wma.net. / http://www.wma.net/en/30publications/10policies/c8/index.html (accessed on 02 20, 2017).

World Medical Association - WMA (n.d.). WMA Declaration of Geneva. Retrieved from https://www.wma.net/policies-post/wma-declaration-of-geneva/ 